\title{
A long-amplicon quantitative PCR assay with propidium monazide to enumerate viable Listeria monocytogenes after heat and desiccation treatments
}

\author{
Kragh, Martin Laage; Thykier, Mikala; Hansen, Lisbeth Truelstrup
}

Published in:

Food Microbiology

Link to article, DOI:

10.1016/j.fm.2019.103310

Publication date:

2020

Document Version

Peer reviewed version

Link back to DTU Orbit

Citation (APA):

Kragh, M. L., Thykier, M., \& Hansen, L. T. (2020). A long-amplicon quantitative PCR assay with propidium monazide to enumerate viable Listeria monocytogenes after heat and desiccation treatments. Food Microbiology, 86, [103310]. https://doi.org/10.1016/j.fm.2019.103310

\section{General rights}

Copyright and moral rights for the publications made accessible in the public portal are retained by the authors and/or other copyright owners and it is a condition of accessing publications that users recognise and abide by the legal requirements associated with these rights.

- Users may download and print one copy of any publication from the public portal for the purpose of private study or research.

- You may not further distribute the material or use it for any profit-making activity or commercial gain

- You may freely distribute the URL identifying the publication in the public portal 
Running Header: Long-amplicon PMA-qPCR assay for enumeration of viable $L$. monocytogenes

1 A long-amplicon quantitative PCR assay with propidium monoazide to enumerate viable

2 Listeria monocytogenes after heat and desiccation treatments

3

4 Martin Laage Kragh, Mikala Thykier and Lisbeth Truelstrup Hansen

8 National Food Institute, Technical University of Denmark, Kemitorvet, DK-2800 Kgs.

$9 \quad$ Lyngby, Denmark

10

11 *Corresponding author: L. Truelstrup Hansen, Telephone+4535886278 litr@food.dtu.dk

12 
Running Header: Long-amplicon PMA-qPCR assay for enumeration of viable $L$. monocytogenes

13 ABSTRACT

14 The objective of this study was to develop a qPCR method for specific enumeration of

15 viable Listeria monocytogenes in food processing facilities and heat treated products.

16 Primers specific for L. monocytogenes were designed to amplify a short (199 bp) or long

17 (1561 bp) fragment of the listeriolysin (hly) gene. The short- and long-amplicon qPCR

18 methods with and without propidium monoazide (PMA) treatment of the cells were tested

19 for their ability to discriminate between viable (no heat) and heat-killed cells $\left(90^{\circ} \mathrm{C}, 10\right.$

20 min). The PMA-qPCR methods were subsequently used to assess the survival of $L$.

21 monocytogenes during desiccation $\left(33 \% \mathrm{RH}, 15^{\circ} \mathrm{C}\right)$ on stainless steel surfaces for ten

22 days with and without prior biofilm formation. The long-amplicon qPCR method had a

23 limit of quantification (LOQ) of $1.32 \log$ CFU/reaction (efficiency 92\%, $\mathrm{R}^{2}=0.991$ ),

24 while the LOQ for the short-amplicon qPCR method was 1.44 log CFU/reaction

25 (efficiency 102\%, $\mathrm{R}^{2}=0.991$ ). PMA was essential for detection of viable cells, and the

26 long-amplicon PMA-qPCR significantly $(p<0.05)$ reduced the signal from heat-killed

27 cells compared to the short-amplicon method. L. monocytogenes survival during

28 desiccation without biofilm formation was accurately enumerated with the long-amplicon

29 PMA-qPCR method. However, when L. monocytogenes had formed biofilm prior to

30 desiccation, the long-amplicon PMA-qPCR accurately measured the log fold inactivation

31 but underestimated the number of viable cells even with use of an optimized DNA

32 extraction method. This long-amplicon PMA-qPCR method can aid in the detection and

33 enumeration of viable L. monocytogenes cells to further the understanding of its survival

34 and persistence in food processing facilities. The developed method was demonstrated to 
Running Header: Long-amplicon PMA-qPCR assay for enumeration of viable $L$. monocytogenes

35 work on both heat and desiccation treated cells and highlights the importance of amplicon

36 size in viability-qPCR.

37 Keywords: Amplicon length, viability, biofilm, stainless steel, PMA-qPCR 
Running Header: Long-amplicon PMA-qPCR assay for enumeration of viable $L$. monocytogenes

\section{INTRODUCTION}

The foodborne bacteria Listeria monocytogenes is repeatedly linked to food recalls and outbreaks of foodborne illness. L. monocytogenes causes the human invasive listeriosis, an infection with high case-fatality (20-30\%) (Allerberger and Wagner, 2010).

L. monocytogenes is very persistent once introduced into a food processing facility and with its ability to grow at low temperatures, contaminated ready-to-eat (RTE) food products such as sliced deli meats, soft cheeses and fresh produce are often involved in outbreaks (Cartwright et al, 2013; Todd and Notermans, 2011). There has been a steady increase in the number of listeriosis cases within EU over the last 10 years with an further increase in 2017 despite the L. monocytogenes content rarely exceeding the EU food safety limit (100 CFU/g) in routine surveillance of RTE foods (EFSA, 2018). A total of 2,480 confirmed cases of listeriosis and 255 related deaths (10\%) were reported in the EU for 2017. Previous studies have shown that the presence of L. monocytogenes on food contact surfaces increases the risk of cross-contamination of foods (Keskinen et al., 2008; Midelet et al., 2006; Rodríguez and McLandsborough, 2007). Recent epidemiological evidence points to persistence of $L$. monocytogenes in food processing environments remaining the major source of RTE food contamination (EFSA BIOHAZ Panel, 2018). Therefore, rapid molecular methods, which specifically detect viable L. monocytogenes, remain of interest in the study and surveillance of the bacterium's survival in the food processing environment including the effect of sanitation strategies.

Compared to culture-based protocols, molecular-based techniques offer rapid detection, increased specificity and enable enumeration of viable but non-culturable cells (VBNC) (Ferrentino et al., 2015). However, DNA-based detection methods such as PCR 
Running Header: Long-amplicon PMA-qPCR assay for enumeration of viable $L$. monocytogenes

may overestimate cell concentrations due to the presence of DNA from dead cells (Josephson et al., 1993). The introduction of the viability dye ethidium monoazide (EMA) and its successor propidium monoazide (PMA) was shown to reduce the signal from dead cells in a way that is not fully elucidated but thought to involve the penetration of the dyes through the leaky membranes of the dead cells followed by formation of covalent crosslinks with the intracellular DNA that then becomes unavailable for PCR amplification (Fittipaldi et al., 2012; Nocker et al., 2006). In theory, PMA cannot penetrate the membrane of 'viable' cells with intact membranes/cell walls and thus should enable accurate enumeration of viable bacteria when combined with qPCR (PMAqPCR). Pan and Breidt (2007) showed linearity between viable L. monocytogenes cells enumerated using PMA-qPCR and plate counts as long as the difference between sanitizer-killed cells and viable cells was no more than 4 log CFU. However, another study with heat-killed L. innocua reported that the use of PMA-qPCR overestimated the number of viable cells in mixes of viable and heat-killed cells (Løvdal et al., 2011). Same study also reported PMA-qPCR to overestimate the number of viable cells (false positive) in samples containing cells killed by heat or isopropanol. Several factors have been studied to improve the signal suppression from dead cells, including PMA concentration, incubation time, incubation temperature, light source for photoactivation, light exposure time, target gene sequence and length of amplicon (Fittipaldi et al., 2012).

Traditionally qPCR assays are based on short amplicons (75-150 bp) to ensure an optimal efficiency, short assay runs and enable the use of hydrolysis probes to increase the specificity of the method (Agilent Technologies, 2012; Nolan et al., 2013). However, early work on a viability end-point PCR assay with EMA showed that a short-amplicon 
Running Header: Long-amplicon PMA-qPCR assay for enumeration of viable $L$. monocytogenes

84 (113 bp) assay was outperformed by a long-amplicon (894 bp) assay when used to test

the viability of $L$. monocytogenes after heat treatment (Soejima et al., 2008). The usefulness of EMA may, however, be limited, as the dye is able into penetrate viable cells and hence caused an underestimation of the viable cell count of L. monocytogenes (Flekna et al., 2007; Nocker et al., 2006). The use of longer amplicons (899 bp and 1512 bp) in combination with the other viability dye, PMA, and qPCR was shown to be superior in suppression of the signal from heat-killed cells of Campylobacter jejuni compared to a 174 bp short-amplicon (Banihashemi et al., 2012). The same study also presented a long-amplicon PMA-qPCR assay for detection of heat-killed Salmonella enterica. Similar results were obtained for Salmonella in cooked ham and with heatkilled Legionella pneumophila in water (Ditommaso et al., 2015; Martin et al., 2013). However, to the best of our knowledge no studies have been published regarding the use of long-amplicon PMA-qPCR to detect viable L. monocytogenes cells in biofilms, or after desiccation or heat treatments.

The objective of this study was to develop a L. monocytogenes specific longamplicon PMA-qPCR assay to allow rapid enumeration of viable L. monocytogenes in the food processing environment. To simulate conditions faced by the bacterium in the food processing industry the assay was tested for its ability to enumerate viable $L$. monocytogenes cells after heat treatment and desiccation on stainless steel with and without prior biofilm formation.

\section{MATERIALS AND METHODS}

\subsection{Bacterial strain and culture conditions}


Running Header: Long-amplicon PMA-qPCR assay for enumeration of viable $L$. monocytogenes

Three strains of L. monocytogenes were used in this study. L. monocytogenes

108

109

110

111

112

113

114

115

EGD-e (Serotype 1/2a, (Murray et al., 1926)) was used in the initial development and validation of qPCR protocols. L. monocytogenes 568 (Serotype 1/2a, (Kalmokoff et al., 2001)), originally isolated from a shrimp processing plant and L. monocytogenes 08-5578 (Serotype 1/2a, (Gilmour et al., 2010)), originally isolated from a human blood sample in the 2008 Canadian listeriosis outbreak, were used in the desiccation survival experiments. Long-term stock cultures were stored in a 20\% (v/v) glycerol peptone medium (TS/80, Technical Service Consultants Ltd, Heywood, UK) at $-80^{\circ} \mathrm{C}$. Routine culturing were done in Tryptic Soy Broth (TSB-glu) ((TSB, Merck, Darmstadt, Germany) supplemented with 1\% (w/v) glucose (Fischer Scientific, Loughborough, UK)) or on Tryptic Soy Agar plates (TSA), composed of 30 g/l TSB and 15 g/l agar (Sigma-Aldrich, St. Louis, MO, USA).

\subsection{Preparation of standardized cell suspensions}

The L. monocytogenes strains were pre-cultured in ten ml TSB-glu overnight at room temperature $\left(22-23^{\circ} \mathrm{C}\right)$ before cells were harvested by centrifugation at $2300 \times g$ for $5 \mathrm{~min}$ and resuspended in TSB-glu to an absorbance at $600 \mathrm{~nm}$ of 1 (NP80 NanoPhotometer, Implen, Westlake Village, CA, USA). The final cell concentrations were approximately $1 \times 10^{8} \mathrm{CFU} / \mathrm{ml}$ as determined by spot plating $(3 \times 20 \mu \mathrm{l})$ of suitable ten-fold dilutions on TSA followed by enumeration after $48 \mathrm{~h}$ incubation at room temperature. In all desiccation experiments, the pre-culturing of $L$. monocytogenes strains was done in TSB-glu at $15^{\circ} \mathrm{C}$ for $48 \mathrm{~h}$. 
Running Header: Long-amplicon PMA-qPCR assay for enumeration of viable $L$. monocytogenes

\subsection{PMA treatment}

Propidium monoazide (PMA, 20 mM, Biotium Inc., Hayward, CA, USA) was kept at $-20^{\circ} \mathrm{C}$ and protected from light until use. Samples with L. monocytogenes cells harvested by centrifugation $(2300 \times g$ for $5 \mathrm{~min})$ in $1.5 \mathrm{ml}$ microcentrifuge tubes were resuspended in one ml peptone saline (PS, 1 g/l Peptone (Oxoid, Hampshire, UK), 8.5 g/l $\mathrm{NaCl}$ (Merck)) before addition of $2.5 \mu \mathrm{PMA}$ to a final concentration of $50 \mu \mathrm{M}$. This concentration was chosen, as it had previously been shown to be effective without being cytotoxic to live cells (Pan and Breidt, 2007; Martin et al., 2013). Each tube was then mixed by vortexing followed by incubation at $15^{\circ} \mathrm{C}$ for $30 \mathrm{~min}$ in the dark together with PMA free control samples. After incubation the tubes with and without PMA added were placed horizontally on ice (to prevent heating) and exposed to a $1000 \mathrm{~W}$ halogen lamp (Videolight 6, Kaiser Video, Germany) for $10 \mathrm{~min}$ at a distance of $20 \mathrm{~cm}$. During the light exposure, the tubes were frequently turned to secure photoactivation and crosslinking of PMA to DNA (Nocker et al., 2006). Both PMA-treated and untreated control samples were centrifuged at 9,900 $\times g$ for 3 min, before the supernatant was discarded and cell pellets frozen at $-20^{\circ} \mathrm{C}$ until DNA extraction.

\subsection{DNA extraction}

DNA from PMA-treated and non-PMA-treated pellets was extracted using the DNeasy PowerSoil Kit (Qiagen) as per the manufacturer's instructions. Extraction of DNA from desiccated cells was modified as described below (see section 2.8.3).

\subsection{Quantitative PCR analysis}


Running Header: Long-amplicon PMA-qPCR assay for enumeration of viable $L$. monocytogenes

Primers and probes (Table 1) for quantitative PCR (qPCR) were designed using the complete reference genome of L. monocytogenes EGD-e (GenBank Accession number NC_003210)(Glaser et al., 2001).

Table 1 Primers and probes used in qPCR and PMA-qPCR assays.

\begin{tabular}{|c|c|c|c|c|}
\hline $\begin{array}{l}\text { Gene } \\
\text { target }\end{array}$ & Name & Sequence $\left(5^{\prime}-3^{\prime}\right)^{\mathrm{a}}$ & Location $^{b}$ & Size (bp) \\
\hline \multirow[t]{3}{*}{ hly } & hly_short_F & $\begin{array}{l}5^{\prime}- \\
\text { TACGCTAAAGAATGCAC } \\
\text { TG-3' }\end{array}$ & $1438-1456$ & \multirow[t]{3}{*}{199} \\
\hline & hly_short_R & $\begin{array}{l}5^{\prime}- \\
\text { GTGTGTGTTAAGCGGTTT } \\
-3^{\prime}\end{array}$ & $+29-(+) 46$ & \\
\hline & hly_short_P & $\begin{array}{l}\text { 5'- Fam } \\
\text { TAGCTTGGGAATGGTGG } \\
\text { AGAACGG-BHQ-1-3' }\end{array}$ & $1460-1483$ & \\
\hline \multirow[t]{2}{*}{ hly } & hly_long_F & $\begin{array}{l}\text { 5'- } \\
\text { TAAAGGGACAGCAGGAC } \\
\text { TAG-3' }\end{array}$ & $(-) 162-(-) 143$ & \multirow[t]{2}{*}{1561} \\
\hline & hly_long_R & $\begin{array}{l}\text { 5'- } \\
\text { ACGATGTGAAATGAGCT } \\
\text { AGC-3' }\end{array}$ & $1379-1399$ & \\
\hline
\end{tabular}

\footnotetext{
${ }^{\mathrm{a}}$ TaqMan probe labels: FAM, fluorescein; BHQ-1, Black Hole Quencher 1. ${ }^{\mathrm{b}}$ Location is given in relation to the translation start site of the target gene (hly). This implies that hly_short_R is placed downstream (+) of $h l y$, while hly_long_F is placed upstream (-) of the hly gene.
}

The L. monocytogenes hly gene was chosen as the gene target based on its length (1590 bp), which would increase the likelihood of designing L. monocytogenes species specific primers with a long (>1500 bp) amplicon. Primers and probes producing a shortamplicon (199 bp) were designed using CLC Workbench (Version 7.9.1, Qiagen

Bioinformatics, Germantown, MD, USA). Primers and probes producing a long-amplicon (1561 bp) were designed using the online freeware tool OligoArchitect ${ }^{\mathrm{TM}}$ Primer and Probe Design (Sigma-Aldrich). Primer species specificity for L. monocytogenes was 
Running Header: Long-amplicon PMA-qPCR assay for enumeration of viable $L$. monocytogenes

170 evaluated using the online NCBI tool Primer-Blast

171 (https://www.ncbi.nlm.nih.gov/tools/primer-blast/) (Jian et al., 2012), while probe

172 specificity was assessed using Blast-n (https://blast.ncbi.nlm.nih.gov/Blast.cgi). All

173 primers and probes were purchased from TAG Copenhagen A/S (Frederiksberg,

174 Denmark). The qPCR protocol for the primers and probe producing a short-amplicon was

175 adapted from Huang et al. (2017) with the qPCR reaction being composed of: $7.7 \mu$ of

176 nuclease-free water, $12.5 \mu \mathrm{l}$ of SsoAdvanced Universal Probes Supermix (Bio-Rad,

177 Hercules, CA, USA)), $0.3 \mu \mathrm{l}$ each of $10 \mu \mathrm{M}$ forward and reverse primers, $0.2 \mu \mathrm{l}$ of $10 \mu \mathrm{M}$

178 TaqMan hydrolysis probe, and $4 \mu \mathrm{l}$ of sample DNA. The long-amplicon qPCR reaction

179 consisted of $7.5 \mu \mathrm{l}$ of nuclease-free water, $12.5 \mu \mathrm{l}$ of Type-it HRM master mix (contains

180 EvaGreen Dye) (Qiagen, Hilden, Germany), $1.0 \mu \mathrm{l}$ each of $10 \mu \mathrm{M}$ forward and reverse

181 primers, and $3 \mu \mathrm{l}$ of sample DNA. The total volume in both qPCR reactions was $25 \mu \mathrm{l}$.

182 qPCR were performed in optical tubes and caps (Agilent Technologies, Santa Clara, CA,

183 USA) on a Stratagene Mx3000p qPCR System (Agilent Technologies) using the

184 following conditions for both the amplicon lengths: initial denaturation for $10 \mathrm{~min}$ at

$18595^{\circ} \mathrm{C}$, followed by 50 cycles of denaturation at $95^{\circ} \mathrm{C}$ for $30 \mathrm{~s}$, annealing at $55^{\circ} \mathrm{C}$ for $30 \mathrm{~s}$

186 and extension at $72^{\circ} \mathrm{C}$ for $1 \mathrm{~min} 45 \mathrm{~s}$. Verification of primer specificity was further

187 confirmed by checking for unspecific products by a melting curve analysis of the qPCR

188 products between $50-95^{\circ} \mathrm{C}$.

189 qPCR standard curves were built using DNA extracts from serial (ten-fold)

190 dilutions of a standardized cell suspension of L. monocytogenes EDG-e. Volumes of $9 \mathrm{ml}$

191 from each dilution (concentrations ranging from $\sim 10^{1}-10^{8} \mathrm{CFU} / \mathrm{ml}$ ) were centrifuged for

19210 min at 2,300 $\times g$ before DNA was extracted from the pellet using the DNeasy 
Running Header: Long-amplicon PMA-qPCR assay for enumeration of viable $L$. monocytogenes

PowerSoil Kit (Qiagen) and stored at $-20^{\circ} \mathrm{C}$. The diluted cultures were also enumerated by spot plating of appropriate dilutions in triplicates on TSA and counted after $48 \mathrm{~h}$ at 22$23^{\circ} \mathrm{C}$. DNA extracted from the diluted standard cell suspensions were analysed by qPCR in triplicates as described above for both amplicon lengths. Quantification cycle threshold (Cq) values were analysed using the MxPro software (Version 4.10, Stratagene). The fluorescent baseline of the standard curves was set using the adaptive baseline tool integrated in MxPro. For other samples analysed with qPCR the fluorescent baseline were adjusted using the means of Cq of positive controls (from the standard curves). Each qPCR run included duplicates of positive and negative (no target DNA) controls. qPCR analysis of DNA from samples treated with PMA are referred to as PMA-qPCR, and used the same conditions as in qPCR analysis of samples prepared without PMA.

The obtained standard curves (Cq values plotted versus the corresponding log CFU/reaction) for the short and long-amplicon assays had efficiencies of 102 and 92\%, respectively, with $\mathrm{R}^{2}$ values of 0.991 for both. The difference in the Cq values between replicates in the standard curves was less than 0.5 .

qPCR amplification products were also analysed by agarose gel electrophoresis to confirm amplicon length. Here, $10 \mu \mathrm{l}$ of amplification product were mixed with $2 \mu \mathrm{l} 6 \times$ DNA-loading dye (New England Biolabs, Beverly, MA, USA) and analysed on a 1\% (w/v) agarose gel (1 g SeaKem® LE Agarose, Lonza, Rockland, ME, USA), 100 ml Trisacetate-EDTA (TAE, VWR, Solon, OH, USA) and $10 \mu \mathrm{l} 10.000 \times$ SYBR ${ }^{\circledR}$ Safe (Invitrogen, Eugene, OR, USA)) at a constant voltage of $80 \mathrm{~V}$ in TAE. The 100-bp Plus GeneRuler Ladder (Fischer Scientific) was used as a DNA marker. The agarose gel was visualized using blue light ( $470 \mathrm{~nm}$ ) in a Gel DOC 2000 (Bio-Rad). 
Running Header: Long-amplicon PMA-qPCR assay for enumeration of viable $L$. monocytogenes

2.6 Enumeration of viable and heat-killed Listeria monocytogenes cells

\subsubsection{PMA treatment.}

To prepare viable and heat-killed (dead) L. monocytogenes EGD-e cells eighteen

221 sterile PCR tubes each containing $100 \mu \mathrm{l}$ of standardized cell suspensions $\left(\sim 1 \times 10^{8}\right.$

$222 \mathrm{CFU} / \mathrm{ml}$ ) of L. monocytogenes EGD-e were either incubated at $90^{\circ} \mathrm{C}$ for $15 \mathrm{~min}$ in a

223 thermocycler (T3000 Thermocycler, Biometra, Göttingen, Germany) to heat-kill cells (9

224 tubes) or left at room temperature for $15 \min$ (9 tubes, controls). Following treatment, 0.9

$225 \mathrm{ml}$ PS was added to each of the eighteen samples. Survivors were determined in three

226 tubes from each treatment by spot plating appropriate dilutions on TSA and enumeration

227 after incubation at $22-23^{\circ} \mathrm{C}$ for $48 \mathrm{~h}$. Three tubes from each treatment were treated with

228 PMA while the three remaining tubes were not, followed by pelleting of cells as

229 described above and storage at $-20^{\circ} \mathrm{C}$ until extraction of DNA using the DNeasy

230 PowerSoil Kit (Qiagen). Samples were stored at $-20^{\circ} \mathrm{C}$ until analyses using the short and

231 long-amplicon qPCR protocols. The resulting Cq values were converted to log CFU/ml

232 equivalents by using the standard curves and taking the dilutions into account.

\subsubsection{Combined PMA and SDS treatment.}

Penetration of PMA into dead cells with compromised cell membranes is

236 instrumental to achieving a successful viability qPCR assay (Nocker et al., 2006). It was

237 thus investigated whether the penetration of PMA into dead L. monocytogenes cells could

238 be improved by a pretreatment with Sodium-Dodecyl-Sulphate (SDS, Sigma-Aldrich) as 
Running Header: Long-amplicon PMA-qPCR assay for enumeration of viable $L$. monocytogenes

previously shown for Escherichia coli (Takahashi et al., 2017). Viable and heat-killed cell pellets were prepared and survivors were enumerated by plate counts as previously described. Duplicate samples of viable or dead cells were treated with all combinations of SDS and PMA (SDS- and PMA- (control), PMA+ SDS-, SDS+ PMA- or SDS+ PMA+).

Briefly, four aliquots of cell pellets from viable and dead treatments were either resuspended in $1 \mathrm{ml}$ of sterilized water with or without $250 \mu \mathrm{g} / \mathrm{ml}$ SDS. The samples were then incubated for $30 \mathrm{~min}$ at $37^{\circ} \mathrm{C}$ before adding $2.5 \mu \mathrm{l}$ of PMA to two of the SDS treated and two of the untreated control samples. The remaining samples received no PMA. The ensuing incubation and light treatment, DNA extraction and qPCR analysis were performed as described above.

\section{7 qPCR detection of viable cells in mixes of viable and heat-killed cells}

L. monocytogenes EGD-e viable and heat-killed (dead) cells were prepared and treated with PMA followed by DNA extraction as described above. DNA extracted from viable L. monocytogenes EGD-e cells was ten-fold diluted in DNA extracted from heatkilled treated L. monocytogenes EGD-e cells in order to assess the influence of a background of dead cells on the enumeration of viable Listeria monocytogenes by PMAqPCR. Four mixes (Table 2) of DNA were prepared: Ten $\mu$ l of DNA from the viable cells was suspended in $90 \mu \mathrm{l}$ nuclease-free water (I, 100\% viable cells). Thirty $\mu$ l DNA from the dead cells were mixed with $270 \mu \mathrm{l}$ nuclease-free water. These working stocks were used to produce the following final mixes of DNA from viable/dead cells (\%): 100/0 (I), 10/90 (II), 1/99 (III), 0.1/99.9 (IV). The mixes of DNA were analysed using both the short-amplicon and long-amplicon qPCR assays as previously described. 
Running Header: Long-amplicon PMA-qPCR assay for enumeration of viable $L$. monocytogenes

Table 2 Mixing ratios of DNA from viable and heat-killed Listeria monocytogenes and their theoretical corresponding cell concentrations (CFU/ml).

\begin{tabular}{llllll}
\hline & $I$ & $I I$ & $I I I$ & $I V$ & 265 \\
\hline Viable & CFU/ml & $10^{7}$ & $10^{6}$ & $10^{5}$ & $10^{4}$ \\
& $100 \%$ & $10 \%$ & $1 \%$ & $0.1 \%$ & \\
Heat-killed CFU/ml & 0 & $9 \times 10^{6}$ & $9.9 \times 10^{6}$ & $9.99 \times 10^{7}$ \\
& $0 \%$ & $90 \%$ & $99 \%$ & $99.9 \%$ & \\
\hline
\end{tabular}

\subsection{Discrimination of viable and dead $L$. monocytogenes during desiccation on} stainless steel

L. monocytogenes 568 and 08-5578 were desiccated on stainless steel for up to ten days with and without prior biofilm formation. Survival of L. monocytogenes was enumerated using plate counts, qPCR and PMA-qPCR as described above. The desiccation of L. monocytogenes on stainless steel was done using a protocol adapted from Hingston et al. (2013).

\subsubsection{Preparation of stainless steel coupons}

The stainless steel (SS, Food grade AISI 316, type 4 finish, thickness $1 \mathrm{~mm}$ ) was cut into coupons of $0.5 \times 0.5 \mathrm{~cm}$. Prior to use, coupons were boiled in $1 \%(\mathrm{w} / \mathrm{v}) \mathrm{SDS}$ solution for $10 \mathrm{~min}$, sonicated for $60 \mathrm{~min}$ with $50 / 60 \mathrm{kHz}$ in a $1000 \mathrm{~W}$ sonication bath (Elmasonic S 120, Fisher Scientific) and immersed in 100\% isopropanol (Sigma-Aldrich) to remove any remaining residues. SS coupons were then rinsed in distilled water, autoclaved and stored in 96\% ethanol (VWR, Fontenay-sous-Bois, France). Before surface inoculation they were rinsed again in distilled water, autoclaved and dried in sterile petri dishes in a biosafety cabinet. 
Running Header: Long-amplicon PMA-qPCR assay for enumeration of viable $L$. monocytogenes

\subsubsection{Inoculation and desiccation of non-biofilm and biofilm $L$. monocytogenes on}

\section{stainless steel}

Before inoculation of the SS coupons, a desiccation chamber (Mini 1 Desiccator Bohlender GmbH, Grünsfeld, Germany) was placed at $15^{\circ} \mathrm{C}$ with three open petri dishes filled with potassium acetate $\left(\mathrm{CH}_{3} \mathrm{COOK}\right.$, Acros Organic, Geel, Belgium) in the bottom of the chamber the day prior to use. This ensured that the temperature and relative humidity $(\mathrm{RH})$ inside the desiccation chamber was stabilized around $15^{\circ} \mathrm{C}$ and $33 \% \mathrm{RH}$ to simulate conditions periodically faced by Listeria monocytogenes in the food processing environment (Hingston et al., 2017). To form a biofilm prior to desiccation of L. monocytogenes 568 and 08-5578 an additional desiccation chamber was placed at $15^{\circ} \mathrm{C}$ with three lid-less petri dishes in the bottom filled with distilled water to create an $\mathrm{RH}$ of $100 \%$. The temperature and $\mathrm{RH}$ were monitored in both desiccation chambers using a built-in logger and a data logger (Tinytag, Gemini Data Loggers Ltd., Chichester, UK). Inoculation of SS coupons was done using standardized cell suspensions of $L$. monocytogenes 568 and 08-5578 pre-cultured in TSB-glu at $15^{\circ} \mathrm{C}$ for $48 \mathrm{~h}$ and resuspended in fresh TSB-glu as described above.

In non-biofilm desiccation experiments, $10 \mu \mathrm{l}$ of L. monocytogenes 568 and 08$5578\left(\sim 1 \times 10^{9} \mathrm{CFU} / \mathrm{ml}\right)$ were spotted separately on individual SS coupons and placed in individual petri dishes without lids inside the desiccation chamber with $15^{\circ} \mathrm{C}$ and $33 \%$ RH for up to ten days.

In biofilm experiments, the SS coupons were inoculated with $10 \mu \mathrm{l}$ of suspensions of L. monocytogenes 568 and 08-5578 (diluted to contain $\sim 10^{4} \mathrm{CFU} / \mathrm{ml}$ ) and the petri dishes with lids were placed in the desiccation chamber with $100 \% \mathrm{RH}$ at $15^{\circ} \mathrm{C}$ for $48-72$ 
Running Header: Long-amplicon PMA-qPCR assay for enumeration of viable $L$. monocytogenes

308 hours to allow growth and biofilm formation before commencement of up to ten days of

309 desiccation by transfer of the samples to a desiccation chamber held at $15^{\circ} \mathrm{C}$ and $33 \%$

310 RH.

\subsubsection{Enumeration and discrimination of viable and dead $L$. monocytogenes on}

313 stainless steel coupons during desiccation

Seven SS coupons from each strain were sampled for enumeration on sampling

315 days over the eight to ten day desiccation period to follow the survival of the two $L$. monocytogenes strains 568 and 08-5578. The SS coupons were placed in individual microcentrifuge tubes containing $1 \mathrm{ml}$ of PS. Adhering cells were released from the SS

318 coupons by sonication for 5 min with $50 / 60 \mathrm{kHz}$ in a sonication bath (Elmasonic S 120)

319 followed by vortexing for $20 \mathrm{~s}$. This protocol for release of bacteria was adapted from the 320 method originally developed by Leriche and Carpentier (1995). Three samples were serial diluted in PS and appropriate dilutions were spot plated on TSA plates. Colonies

322 were enumerated after incubation for $48 \mathrm{~h}$ at room temperature and expressed as log

$323 \mathrm{CFU} / \mathrm{cm}^{2}$. The content of the four remaining samples were transferred to four new 324 microcentrifuge tubes, followed by the PMA treatment of two of these samples by 325 addition of $2.5 \mu \mathrm{l}$ PMA to a final concentration of $50 \mu \mathrm{M}$. Further treatment, isolation of 326 cell pellets and freezing of cell pellets were done as described above. using the DNeasy PowerSoil Kit (Qiagen) and elution in $100 \mu$ l Elution Buffer (EB,

330 Qiagen). 
Running Header: Long-amplicon PMA-qPCR assay for enumeration of viable $L$. monocytogenes

In order to optimize the DNA extraction from L. monocytogenes biofilm cells the DNeasy PowerBiofilm DNA extraction (Qiagen) was tested with and without a pretreatment cell lysis protocol. The DNA extraction from the biofilm desiccation experiments spanning ten days was done with this pretreatment to optimize the lysis of the Gram-positive L. monocytogenes biofilm cells before proceeding to the DNA extraction using the DNeasy PowerBiofilm Kit. The cell lysis protocol was adapted from an optional pretreatment described in the DNeasy Blood \& Tissue Kit (Qiagen, 2006) with the following protocol: $180 \mu \mathrm{l}$ of freshly prepared enzymatic lysis buffer (20 mM Tris-Cl pH 8.0, 2 mM sodium EDTA, 1.2\% Triton X-100, 20 mg/ml lysozyme) was added directly to frozen cell pellets and incubated in a standard laboratory heat block for 20 min at $37^{\circ} \mathrm{C}$ with 550 rpm (ThermoMixer C, Eppendorf, Hamburg, Germany) The pretreatment was continued by addition of $25 \mu$ l Proteinase K (>600 mAU/ml) and vortexed $10 \mathrm{~s}$ before incubation in the heat block for $30 \mathrm{~min}$ at $56^{\circ} \mathrm{C}$ with $550 \mathrm{rpm}$. After incubation the DNA was extracted using the DNeasy PowerBiofilm Kit, where the protocol was followed from step two with the modification that the liquid from the pretreated samples was mixed with the first solution of the kit and transferred to the PowerBiofilm Bead tube. DNA was eluted in $100 \mu \mathrm{l}$ EB as in the other DNA extractions. DNA extracted with or without PMA treatment from cells from the desiccation experiments was analyzed with qPCR using the long-amplicon protocol as previously described. Cq values were converted to $\log \mathrm{CFU} / \mathrm{cm}^{2}$. qPCR was done in duplicates with negative and positive controls.

To assess the accuracy of the enumerations by PMA-qPCR compared to plate counts the accuracy factor $\left(A_{f}\right)$ described by Ross (1996) was calculated: 
Running Header: Long-amplicon PMA-qPCR assay for enumeration of viable $L$. monocytogenes

$354 \quad A_{f}=10^{\sum\left|\log \left(\frac{\text { predicted }}{\text { observed }}\right)\right|}$

Where $\mathrm{n}$ is the total number of data points. A value of 1 means there is complete agreement between the "predictions” (plate counts) and “observations” (qPCR results); whereas a value of 1.10 means that the predictions on average are $10 \%$ within the observations.

The qPCR, PMA-qPCR and plate count results were normalized $\left(\log \left(\mathrm{N}_{\mathrm{t}} / \mathrm{N}_{0}\right)\right.$ to allow comparison of the inactivation measured by the different methods (Fig. 5a) and to compare the inactivation determined by qPCR relative to the observations from plate counts (Fig. 5b).

In order to further optimize the enumeration by qPCR and PMA-qPCR a standard curve based on samples taken during biofilm formation was produced. Briefly, triplicate samples of plate counts and DNA were obtained by harvesting cells from SS coupons during 48 hours of biofilm formation as before. DNA from these cells was extracted using the optimized protocol with the lysis pretreatment and the DNeasy PowerBiofilm Kit and subjected to qPCR analyses.

\subsection{Statistical analysis}

All plate counts were done in triplicates while qPCR results were from analyses of at least duplicate samples. For enumeration of the viable and heat-killed cells, paired ttests were performed on $\log (\mathrm{CFU} / \mathrm{ml})$ values to test for differences between plate counts, qPCR and PMA-qPCR results obtained from either the short or long-amplicon based qPCR protocols. Statistical analysis of the difference between the enumeration methods used for discrimination of viable and dead cells during desiccation of L. monocytogenes 
Running Header: Long-amplicon PMA-qPCR assay for enumeration of viable $L$. monocytogenes

used the analysis of variance (ANOVA) on the normalized inactivation values to compare PMA-qPCR to the plate count inactivation values. This included a Tukey's HSD (honest significant difference) test at the $5 \%$ significance level. For all data $p<0.05$ was considered statistically significant.

\section{RESULTS}

\subsection{Performance of $q P C R$ assays}

The original aim was to develop short and long-amplicon Taqman qPCR methods for specific detection of L. monocytogenes. However, in spite of trying different probe designs the long-amplicon qPCR assay with probe exhibited low efficiencies of $\leq 83 \%$.

Primers for the long-amplicon qPCR were instead designed to be species specific without a probe as confirmed by Primer-Blast and melt-curves of amplicons. The Primer-Blast and Blast-n analyses of the primers and probe showed that for the short-amplicon qPCR method, the probe was needed to attain species specificity. Non-specific products were not seen in the melt-curve analyses of either amplicon lengths and agarose gel electrophoresis confirmed this observation and the length of amplicons. The standard curves led to calculated efficiencies of 102 and 92\% (slopes -3.3 and -3.5) for the shortamplicon with probe and the long-amplicon without probe qPCR assays, respectively, and $\mathrm{R}^{2}$ values of 0.991 for both assays (Fig. S1 in the supplemental material). The limit of quantification (LOQ) for the qPCR assays was determined as the lowest concentration within the linear portion of the standard curve as recommended in the MIQE Guidelines (Bustin et al. 2009) and were 1.44 and $1.32 \log$ CFU/reaction for the short-amplicon and long-amplicon qPCR assays, respectively, corresponding to $6886 \mathrm{CFU} / \mathrm{ml}$ and 6964 
Running Header: Long-amplicon PMA-qPCR assay for enumeration of viable $L$. monocytogenes

\subsection{Effect of amplicon size on discrimination between viable and dead cells} pretreated with PMA

Plate counts before and after heat treatment $\left(90^{\circ} \mathrm{C}\right.$ for $\left.15 \mathrm{~min}\right)$ of $L$. monocytogenes showed that the heat treatment was effective in killing the cells, i.e., the reduction was from $8.02 \log \mathrm{CFU} / \mathrm{ml}$ to below the detection limit of $1.22 \log \mathrm{CFU} / \mathrm{ml}$.

The treatment of heat-killed L. monocytogenes with $50 \mu \mathrm{M}$ PMA prior to DNA extraction caused a significantly increase in Cq values (by 13 cycles and 18 cycles) for the short- or long-amplicon PMA-qPCR protocols compared to PMA-qPCR of viable cells. This corresponded to a reduction in viable cells of $4.2 \log$ CFU/ml and $5.1 \log$ CFU $/ \mathrm{ml}$ for the short- and long-amplicon qPCR, respectively.

As shown in Fig. 1, the log CFU/ml result from long-amplicon PMA-qPCR assay fell below its LOD, whereas the signal suppression in the short-amplicon PMA-qPCR assay was incomplete leading to detection of a false positive log CFU/ml above the LOD. PMA $(50 \mu \mathrm{M})$ treatment had no significant $(p>0.05)$ toxic effect on plate counts (data not shown). qPCR and PMA-qPCR with either amplicon size caused a slight but insignificant $(p>0.05)$ underestimation of the viable cell count. 
Running Header: Long-amplicon PMA-qPCR assay for enumeration of viable $L$. monocytogenes

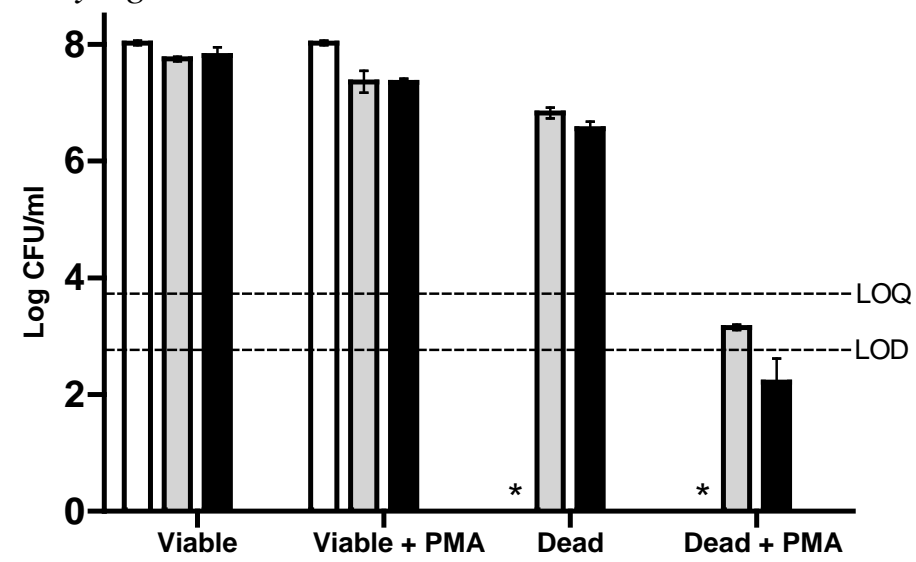

Figure 1. Effect of amplicon length and PMA treatment on qPCR detection of viable and heat-killed L. monocytogenes. Viable and heat-killed (dead) L. monocytogenes were enumerated by plate counts ( $\square$ ) and the short-amplicon (SA, 199

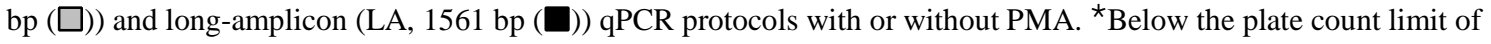
dectection $\left(\mathrm{LOD}_{\text {platecount }}=1.22 \log \mathrm{CFU} / \mathrm{ml}\right.$. $)$ The horizontal dashed lines correspond to the limits of quantification (LOQ) and detection (LOD) for the LA-qPCR of 3.84 and $2.84 \log$ CFU/ml, respectively. Bars are averages of replicates $(n=6)$ and error bars indicate standard deviation.

The membrane destabilization pretreatment with SDS prior to PMA treatment did not significantly $(p>0.05)$ enhance the effect of PMA in removing the false-positive DNA signal from heat-killed cells in long-amplicon PMA-qPCR (data not shown). Additionally, SDS appeared to have a toxic effect on viable L. monocytogenes cells and use of SDS treatment was not further investigated.

In the test of the ability of the short- and long-amplicon PMA-qPCR assays to enumerate viable $L$. monocytogenes in mixes of DNA from PMA treated dead and viable cells (Table 2), both amplicon lengths accurately quantified viable cells in the $100 \%$ viable cell mix (Fig. 2). However, when the short-amplicon was used to quantify the viable cells in samples containing increasing concentrations of DNA from dead PMA treated cells, a log fold reduction in the signal between each mix was not observed. In contrast, the long-amplicon qPCR quantified the concentration of viable cells resulting in values that were similar to the theoretically calculated plate counts for each mix (Table 
Running Header: Long-amplicon PMA-qPCR assay for enumeration of viable $L$. monocytogenes

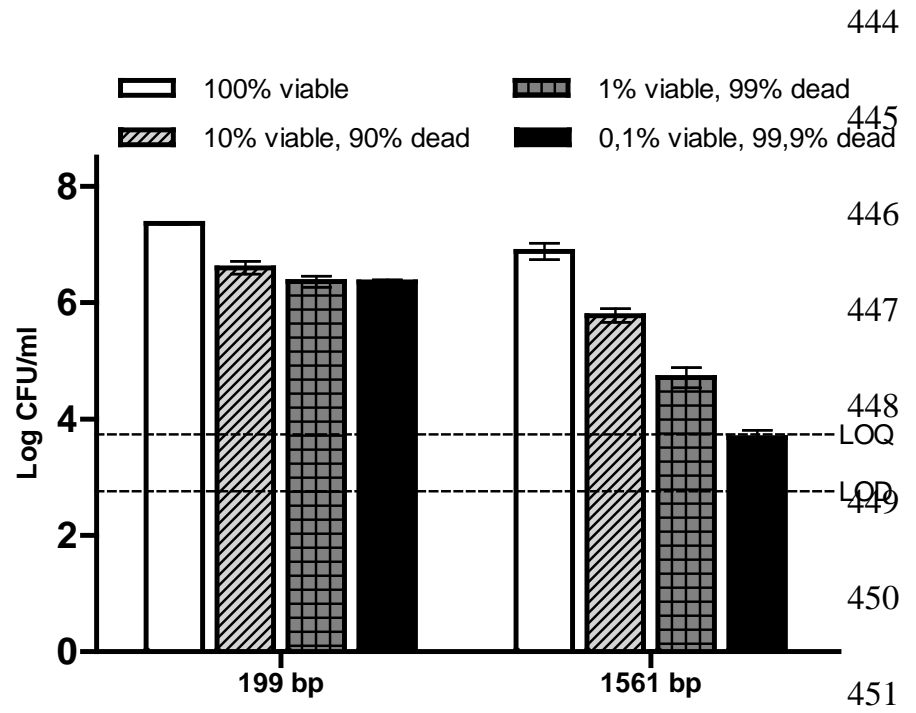

Figure 2. Effect of amplicon length on the ability of PMA-qPCR to detect viable cells in mixes of viable and heatkilled (dead) cells. DNA from viable cells was diluted in DNA from PMA treated dead cells and tested using PMAqPCR. The horizontal dashed lines correspond to the LOQ and LOD for the PMA-qPCR of 3.84 and $2.84 \log$ CFU/ml, respectively. Bars are averages of replicates $(\mathrm{n}=8)$ and error bars indicate standard deviation. steel

According to the plate counts, the survival of L. monocytogenes decreased

460 steadily for both strains during desiccation for ten days on stainless steel at $15^{\circ} \mathrm{C}$ and 33\% RH (Fig. 3). As it can be seen in Fig. 3 the effect of omitting the PMA treatment

462 prior to DNA extraction resulted in a significant $(p<0.05)$ overestimation of the number 463 of viable cells by the long-amplicon qPCR assay. This overestimation of surviving cells 464 is evident from the first day and stable throughout the desiccation period. Without PMA 
Running Header: Long-amplicon PMA-qPCR assay for enumeration of viable $L$. monocytogenes

465 the accuracy factor of the long-amplicon qPCR compared to the plate count was 1.18 and $466 \quad 1.26$ for L. monocytogenes $08-5578$ and 568, respectively.
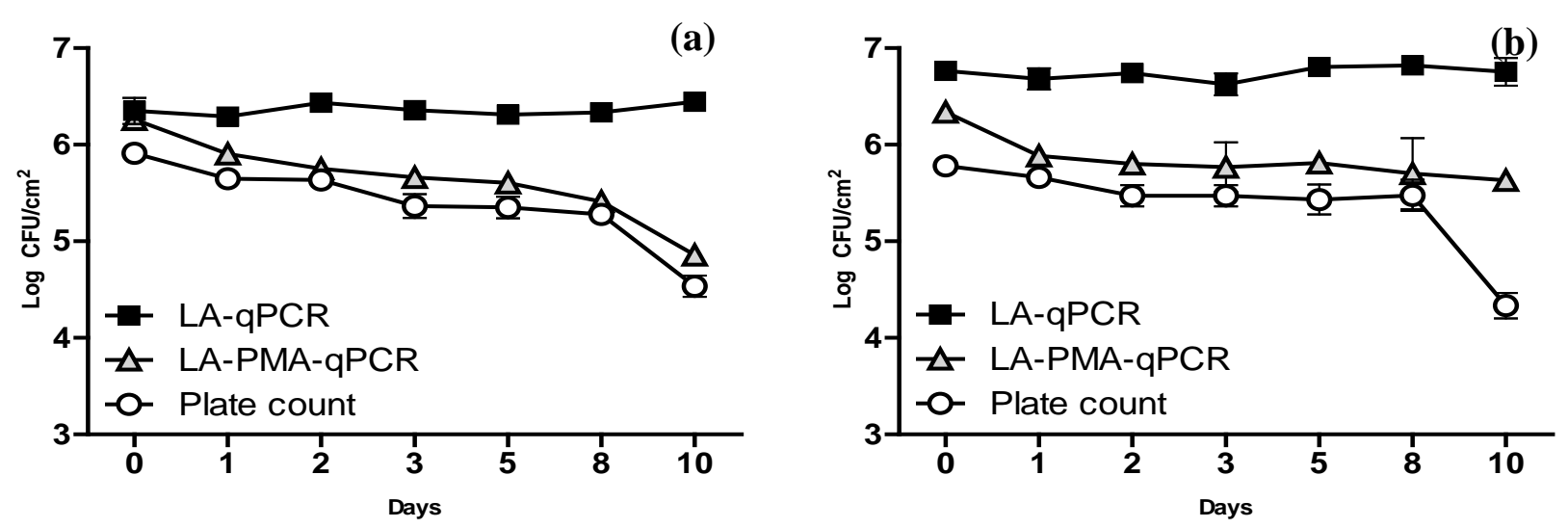

Figure 3. Desiccation survival of L. monocytogenes 08-5578 (a) and 568 (b) on stainless steel coupons. Cells were precultured at $15^{\circ} \mathrm{C}$ in TSB-glu and re-suspended in TSB-glu and desiccated $\left(33 \% \mathrm{RH}, 15^{\circ} \mathrm{C}\right)$ for 10 days. Cells were enumerated by plate counts (O) and the long-amplicon (1561 bp) qPCR protocol with $(\Delta)$ or without (ם) PMA. Symbols are averages of replicates $(n=2-4)$ and error bars indicate standard deviation. significant difference $(p>0.05)$ between the PMA-qPCR and plate counts. The PMAqPCR result was consistent for both strains (accuracy factors of 1.05 and 1.09, respectively) throughout the experiment except for day 10 in L. monocytogenes 568, where the PMA-qPCR overestimated the viable cell concentration. At day 10 both strains 478 exhibited a remarkable drop in culturable survivors as estimated by plate counts, which was also seen with PMA-qPCR for L. monocytogenes 08-5578. The plate count

480 quantified the overall reduction of culturable cells to $1.38 \pm 0.11 \log C F U / \mathrm{cm}^{2}$ for $L$. 481 monocytogenes $08-5578$ and $1.45 \pm 0.11 \log$ CFU/ $\mathrm{cm}^{2}$ for L. monocytogenes 568. In comparison, the reduction of viable cells measured by PMA-qPCR was $1.40 \pm 0.09 \log$ 
Running Header: Long-amplicon PMA-qPCR assay for enumeration of viable $L$. monocytogenes

\subsection{Enumeration of viable Listeria monocytogenes biofilms during desiccation on} stainless steel

The study of the performance of the long-amplicon PMA-qPCR assay in the detection of viable $L$. monocytogenes in pre-formed biofilms (48 hours at $15^{\circ} \mathrm{C}$ and $100 \%$ $\mathrm{RH}$ ) being desiccated for eight days at $15^{\circ} \mathrm{C}$ and $33 \% \mathrm{RH}$ was designed to probe the fate of L. monocytogenes left on insufficiently cleaned or soiled surfaces of stainless steel processing equipment in an environment, where $\mathrm{RH}$ varies due to non-continuous production activity. The plate count results showed that overall desiccation survival of $L$. monocytogenes 568 biofilm cells (Fig. 4a) were better than for the non-biofilm cells (Fig. 3b). The long-amplicon PMA-qPCR results from the first biofilm desiccation experiment using DNA from the DNeasy PowerSoil Kit, followed the decreasing trend in survivors but significantly $(p<0.05)$ underestimated the biofilm cell count by on average 2.21 log $\pm 0.26 \mathrm{CFU} / \mathrm{cm}^{2}$ compared to the plate count, as also evident in an accuracy factor of 1.48. As long-amplicon qPCR apparently detects listerial DNA from both viable and dead cells, this method was not expected to underestimate biofilm cell concentrations compared to plate counts as was observed with stable levels of $\sim 5-5.5 \log$ CFU/cm² (Fig. 4a). Consequently, it was hypothesized that the low cell estimates (i.e., low DNA concentrations) could be caused by insufficient DNA extraction from the biofilm cells. Use of the DNeasy PowerBiofilm Kit caused a significant $(p<0.05)$ improvement (data 
Running Header: Long-amplicon PMA-qPCR assay for enumeration of viable $L$. monocytogenes

506 not shown), but the underestimation persisted. Next, two different cell lysis treatments

507 (see section 2.8.3) were tested to improve the DNA extraction from aggregated biofilm

508 cells (Colagiorgi et al., 2016). Both lysis treatments reduced the underestimation of cell

509 numbers by the qPCR (data not shown).
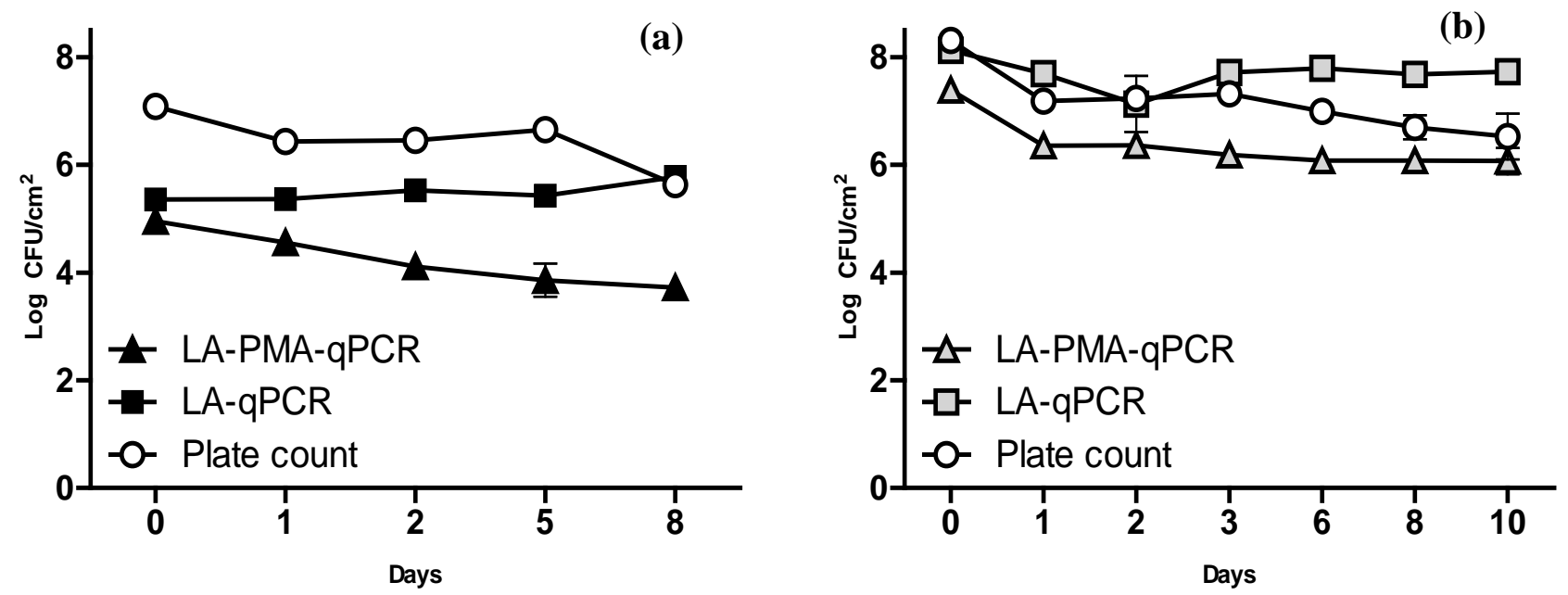

510

511 Figure 4. Survival of L. monocytogenes 568 biofilm cells during desiccation on stainless steel coupons, as enumerated

512 by plate counts (O) and the long-amplicon qPCR protocol using DNA extracted either with (a) the DNeasy PowerSoil

513 DNA Kit $(\mathbf{\Delta , \square}$ ) or (b) a modified DNeasy PowerBiofilm Kit $(\Delta, \square)$ with $(\Delta)$ or without $(\square)$ PMA treatment prior to

514 DNA extraction (averages of replicates $(n=3)$ with standard deviation). Cells were spotted on stainless steel coupons

515 and kept at $100 \% \mathrm{RH}$ for $48-72 \mathrm{~h}$ to allow biofilm formation prior to desiccation $\left(15^{\circ} \mathrm{C}, 33 \% \mathrm{RH}, 8-10\right.$ days). Day 0

516 represents the beginning of desiccation.

Use of the best-performing cell lysis/DNA extraction protocol with the longamplicon PMA-qPCR in a new biofilm desiccation experiment still resulted in a

520 significant $(p<0.05)$ underestimation of the cell concentration by an average of $0.82 \pm$

$5210.31 \log \mathrm{CFU} / \mathrm{cm}^{2}$ cell compared to the plate count (Fig. 4b). The accuracy factor was,

522 however, improved to 1.14. Moreover, when assessing the relative inactivation (log 
Running Header: Long-amplicon PMA-qPCR assay for enumeration of viable $L$. monocytogenes

$\left.523\left(\mathrm{~N}_{\mathrm{t}} / \mathrm{N}_{0}\right)\right)$ in both biofilm experiments it became evident that long-amplicon PMA-qPCR

524 correctly enumerated the relative reduction in viable cells during desiccation of the

525 biofilm and agreed with the reduction observed by the plate count $\log \left(\mathrm{N}_{t} / \mathrm{N}_{0}\right)$ (Fig. 5a). In

526 contrast, the cell concentrations measured by long-amplicon qPCR stayed constant

527 leading to increasing differences relative to plate count results, which was not the case for

528 long-amplicon PMA-qPCR (Fig. 5b).
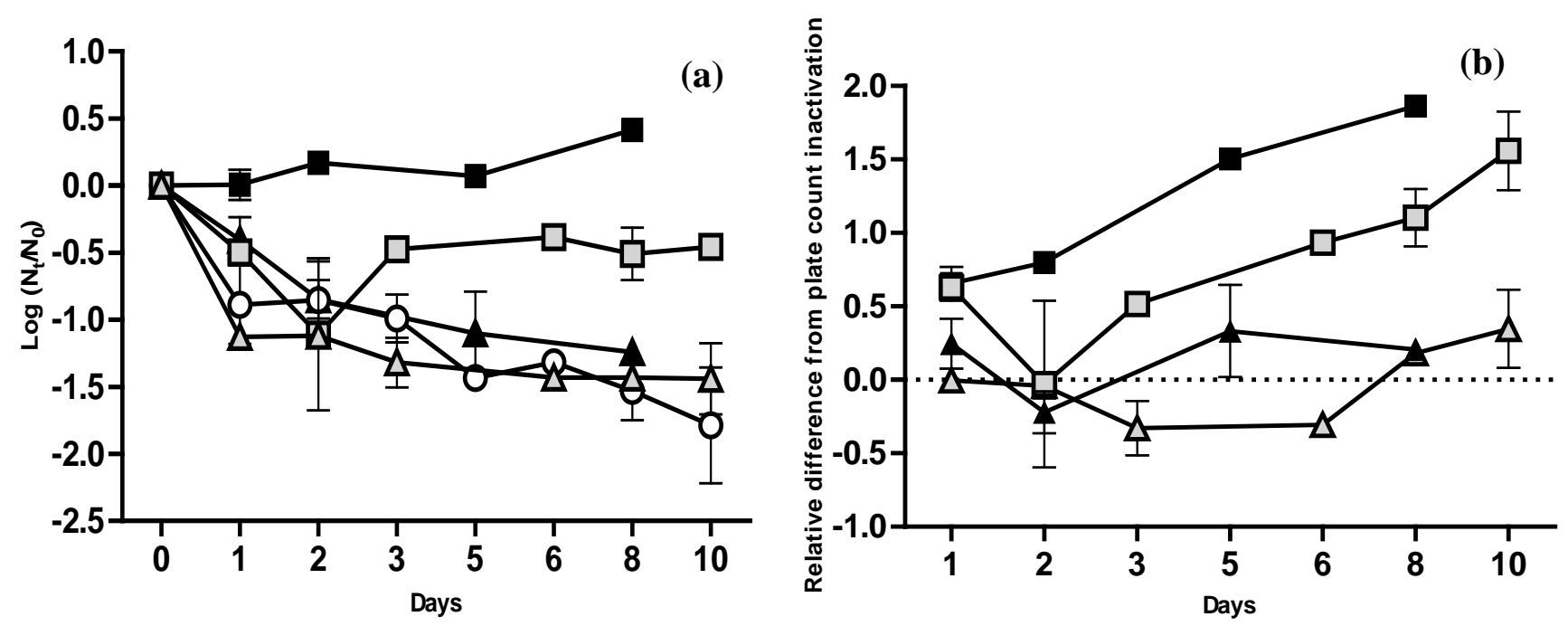

Figure 5. Optimization of DNA preparation for the long-amplicon qPCR protocols to detect (a) the relative reduction ( $\left.\log \left(\mathrm{N}_{\mathrm{t}} / \mathrm{N}_{0}\right)\right)$ in viable cells counts and (b) the difference between qPCR results and plate counts during desiccation $\left(15^{\circ} \mathrm{C}, 33 \%\right.$ RH, 8-10 days) of biofilm cells of $L$. monocytogenes 568 on stainless steel. Survivors were enumerated by plate counts $(\mathrm{O})$ and the long-amplicon qPCR protocol using DNA extracted either with (a) the DNeasy PowerSoil DNA Kit $(\boldsymbol{\triangle}, \square)$ or (b) a modified DNeasy PowerBiofilm Kit $(\Delta, \square)$ with $(\Delta)$ or without ( $\square$ ) PMA treatment prior to DNA extraction (averages of replicates ( $\mathrm{n}=3$ ) with standard deviation). the gap between plate counts and the cell concentrations calculated using the longamplicon PMA-qPCR standard curve derived from planktonic cells (data not shown). 
Running Header: Long-amplicon PMA-qPCR assay for enumeration of viable $L$. monocytogenes

4. DISCUSSION

\subsection{Effect of amplicon size on discrimination between viable and dead cells} pretreated with PMA

PMA treatment of L. monocytogenes samples prior to DNA extraction coupled with qPCR (PMA-qPCR) proved to be a valid method for enumeration of viable cells. When preparations of dead cells were analyzed by PMA-qPCR, the long-amplicon assay significantly improved the suppression of the false-positive signal from the dead cells. These findings were in line with observations from other PMA-qPCR studies, where shorter and longer amplicon assays were compared for enumeration of viable Campylobacter, Salmonella and Legionella (Banihashemi et al. 2012; Martin et al. 2013;

Ditommaso et al. 2015). While the present study is to the best of our knowledge the first to develop a long-amplicon PMA-qPCR assay that is specific for L. monocytogenes, Soejima et al. (2008) showed in an EMA end-point PCR assay that a longer amplicon (894 bp) improved detection of survivors after heat-treatment of L. monocytogenes compared to a short-amplicon (113 bp) assay.

The signal detected from the heat-killed cells by the long-amplicon PMA-qPCR method fell below the LOD, whereas the signal in the short-amplicon PMA-qPCR remained above LOD (Fig 1). Some studies interpret a qPCR signal below LOD as a complete suppression of the 'dead signal' and thus depict bars in figures with the measured cell concentration as zero for these observations (Banihashemi et al., 2012;

Ditommaso et al., 2015). Others show the obtained Cq value or the increase in Cq without explicit information about the LOD (Martin et al., 2013; Thanh et al., 2017). This 
Running Header: Long-amplicon PMA-qPCR assay for enumeration of viable $L$. monocytogenes

makes direct comparisons between studies regarding the complete and incomplete suppression of the 'dead signal' difficult.

When DNA from different concentrations of viable cells was quantified in a background of DNA from high concentrations of dead cells, the long-amplicon PMAqPCR assay accurately enumerated the viable cells, whereas the short-amplicon PMAqPCR assay failed to differentiate between viable and dead cells (Fig. 2). The inability of the short-amplicon PMA-qPCR assay to accurately enumerate the viable cell concentrations below $6 \log \mathrm{CFU} / \mathrm{ml}$ is consistent with the findings of Løvdal et al. (2011), where a short-amplicon (101 bp) PMA-qPCR assay was able to enumerate viable cells in mixes of viable and heat-killed cells of Listeria innocua, but only when the viable cell concentration was $\geq 6 \log \mathrm{CFU} / \mathrm{ml}$. Similar observations have been done for Salmonella, where a short-amplicon (95 bp) could not accurately enumerate the viable cells in a background of DNA from $10^{8} \mathrm{CFU} / \mathrm{g}$ dead cells, if the concentration of viable Salmonella was $\leq 6 \log$ CFU/g (Martin et al., 2013). In agreement with the finding from the present study, increasing the amplicon size from 95 to 417 bp enabled accurate enumeration of viable cells in concentrations $\geq 10^{3} \mathrm{CFU} / \mathrm{g}$ in a background of dead Salmonella (Martin et al., 2013).

The reason for improved performance of longer amplicons in PMA-qPCR and EMA-qPCR assays in the discrimination of viable and dead cells is not known. It is thought that PMA and EMA suppresses the qPCR signal from cells with a compromised membrane by introducing random cross-links between PMA or EMA and cellular DNA, which limits amplification of cellular DNA in a way that is not fully elucidated (Fittipaldi et al., 2012; Nocker et al., 2006). The longer sequences used in long-amplicon PMA- 
Running Header: Long-amplicon PMA-qPCR assay for enumeration of viable $L$. monocytogenes

qPCR assays logically increase the likelihood of PMA cross-links and the prevention of a qPCR signal. Soejima et al. (2011) showed a positive correlation between the signal suppression from dead cells and the amplicon length in EMA-qPCR in a study with varying amplicon lengths ranging from 110 to $2840 \mathrm{bp}$. Our results for L. monocytogenes and similar findings in other foodborne pathogens underpin the importance of using longer amplicons in viability PMA-qPCR assays in contrast to traditional guidelines for qPCR which recommends short-amplicons (75-300 bp, Nolan et al. 2013; Agilent Technologies 2012).

Attempts to further improve the long-amplicon PMA-qPCR method by implementation of a SDS pre-treatment step as suggested by Takahashi et al. (2017) failed for the L. monocytogenes assay. It may be that this method originally developed for the Gram-negative Escherichia coli cannot be used for Gram-positive bacteria, likely due to the observed toxic effect of SDS on L. monocytogenes.

\subsection{Long-amplicon PMA-qPCR as a method to discriminate between viable and}

\section{dead Listeria monocytogenes during desiccation on stainless steel}

Listeria monocytogenes is capable of surviving up to at least 90 days on stainless steel, which is a widely used material in the food industry (Vogel et al., 2010). To test the ability of the assay to accurately enumerate viable $L$. monocytogenes in a food processing facility (e.g., tables, slicers, conveyor belts, drains, etc.), the assay was tested on cells being desiccated on stainless steel. Enumeration of survivors during ten days of desiccation by long-amplicon PMA-qPCR and plate counts was not significantly ( $p$ > 0.05) different, although the long amplicon PMA-qPCR assay tended to overestimate 
Running Header: Long-amplicon PMA-qPCR assay for enumeration of viable $L$. monocytogenes

609 viable cells compared to the plate counts (Fig. 3). The slight overestimation of viable 610 cells may possibly be explained by the presence of VBNC cells as also implied by

611 Overney et al. (2017), who using a short amplicon (113 bp) PMA-qPCR assay observed a 612 higher number of viable cells compared to culturable cells after 24 hours of desiccation 613 on stainless steel in different media. This observation may perhaps also be explained by 614 the amplicon length, as the present study observed a greater discrepancy between plate 615 counts and short-amplicon PMA-qPCR results (Fig. S2) than were the case for the long616 amplicon results when enumerating desiccation survivors. To determine if the minor 617 overestimation of viable cells by the long-amplicon PMA-qPCR assay during the 618 desiccation experiment is due to the presence of VBNC L. monocytogenes evidence from 619 other experimental approaches would be needed such as metabolic activity tests, ongoing 620 mRNA synthesis, CTC counts or flow cytometry (Besnard et al., 2000; Lindbäck et al., 621 2010; Winkelströter and De Martinis, 2015). In a study of the efficiency of SC-CO 622 pasteurization treatment to inactivate L. monocytogenes spiked on dry cured ham, flow 623 cytometry coupled (FCM) with SYBR-Green I and short amplicon (101 bp) PMA-qPCR 624 was used to enumerate membrane intact (viable) cells (Ferrentino et al., 2015). Both 625 methods indicated high amounts of VBNC cells as the reduction $\left(\log \mathrm{N}_{\mathrm{t}} / \mathrm{N}_{0}\right)$ of "viable” 626 cells compared to plate counts was much lower with short amplicon PMA-qPCR and 627 FCM indicating the presence of approximately 4 and $2 \log$ VBNC cells, respectively. 628 Thus our measurement of an average of $0.35 \log \mathrm{CFU} / \mathrm{cm}^{2} \mathrm{VBNC}$ cells by the long629 amplicon PMA-qPCR assay in our study, is markedly lower and may perhaps be 630 explained by the improved suppression of signal from dead cells obtained due to the 631 increased amplicon length. 
Running Header: Long-amplicon PMA-qPCR assay for enumeration of viable $L$. monocytogenes

632

633

\subsection{Limitations of long-amplicon PMA-qPCR as a method for direct enumeration of} viable Listeria monocytogenes biofilm cells during desiccation on stainless steel.

The long-amplicon PMA-qPCR assay was also tested on L. monocytogenes 085578 and 568 biofilms being desiccated on stainless steel. The first protocol yielded a significant $(p<0.05)$ underestimation of both viable and total cells as measured by longamplicon PMA-qPCR and qPCR, respectively, compared to plate counts (Fig. 4a). The PMA-qPCR underestimated the viable cells in the desiccated biofilm by an average of $2.21 \log \pm 0.26 \mathrm{CFU} / \mathrm{cm}^{2}$ which was in contrast to the non-biofilm experiments where there was an insignificant $(p>0.05)$ overestimation. Winkelströter and De Martinis (2015) also reported an underestimation of $2 \log \mathrm{CFU} / \mathrm{ml}$ when attempting to enumerate biofilm cells of L. monocytogenes using EMA-qPCR. They explained this observation as having been caused by the cytotoxicity of EMA. PMA has, however, been shown not to be cytotoxic to L. monocytogenes at effective concentrations (50 $\mu \mathrm{M})$ (Pan and Breidt, 2007) and should not be responsible for the observed PMA-qPCR underestimation of viable L. monocytogenes biofilm cells during desiccation. In view of the current understanding of the mechanism of PMA and the presence of extracellular DNA (eDNA) in the biofilm matrix of $L$. monocytogenes one might actually have expected that the viable biofilm cells would be overestimated if PMA were to bind to eDNA instead of entering dead cells (Colagiorgi et al., 2016). As the underestimation of viable cells occurred in both the qPCR and PMA-qPCR results, it is more likely to be explained by factors relating to biological differences between planktonic cultures and biofilms of $L$. monocytogenes. Indeed, optimization of the cell lysis and the use of a DNA extraction kit 
Running Header: Long-amplicon PMA-qPCR assay for enumeration of viable $L$. monocytogenes

655 commercially designed for biofilm cells (DNeasy PowerBiofilm kit) reduced the underestimation in both assays. The underestimation of viable cells by long-amplicon PMA-qPCR was reduced from $2.21 \log \mathrm{CFU} / \mathrm{cm}^{2}$ to $0.82 \log \mathrm{CFU} / \mathrm{cm}^{2}$ as compared to plate counts (Fig. 4b). The long-amplicon PMA-qPCR enumeration was still significantly $(p<0.05)$ lower than the plate counts. However, when looking at the inactivation during desiccation in relation to the starting concentration $\left(\log \mathrm{N}_{\mathrm{t}} / \mathrm{N}_{0}\right)$ as determined by either qPCR or PMA-qPCR, it became evident that the long-amplicon PMA-qPCR accurately enumerated the loss of viable cells regardless of the DNA extraction method, while the long-amplicon qPCR assay did not (Fig. 5b). This means that the long-amplicon PMAqPCR method developed in the present study accurately measured the relative inactivation of $L$. monocytogenes biofilm cells during the desiccation treatment but could not be used to estimate the "exact" viable cell concentrations.

Interestingly, the underestimation in the PMA-qPCR assay seemed to be related to a lower cellular DNA content or DNA extraction efficiency from L. monocytogenes biofilm cells being desiccated. In a study of qPCR detection of $L$. monocytogenes biofilms (without viability dyes) four different DNA extraction methods were tested by Guilbaud et al. (2005) on both adherent and non-adherent cells and found to performed differently on the two types of cells. More effort will have to be made in order to optimize the DNA extraction from biofilm cells if an accurately enumeration of viable $L$. monocytogenes is desired.

Comparison of qPCR standard curves made from L. monocytogenes planktonic and wet biofilm cells grown on stainless steel revealed no significant $(p>0.05)$ differences, meaning that PCR inhibitors in the biofilm seemed less likely to have been 
Running Header: Long-amplicon PMA-qPCR assay for enumeration of viable $L$. monocytogenes

678 responsible for the underestimation by both the long-amplicon qPCR and PMA-qPCR 679 assays.

In general the results from the present study add to the mounting evidence that increasing the amplicon length in PMA-qPCR improves the suppression of the signal from dead cells and the ability to discriminate between viable and dead cells. One drawback of long-amplicon PMA-qPCR is the increased runtime, which is, however, negligible compared to the time it takes to use culture dependent methods. A new version of PMA called PMAxx has been marketed by Biotium, which in Salmonella has shown to improve suppression of the dead signal (Biotium, 2013). The number of studies using PMAxx is, however, still limited and has mainly been used in studies with viruses. Also of great interest is the recently developed dye PEMAX, marketed by GenIUL, which takes advantage of two photoreactive dyes and has shown to effectively suppress the signal from dead Salmonella enterica in 33 food samples using a 262 bp amplicon membranes but no ATP turnover (Codony et al., 2015). Other compounds such as palladium (Pd-qPCR) and platinium (Pt-qPCR) have shown to be a competitive and 695 cheaper choice for viability-qPCR with very comparable results to PMA-qPCR and thus 696 further studies should compare PMA and PMAxx with these alternative compounds. inactivation methods (e.g., isopropanol, non-thermal plasma, thermal lysis, autoclaving,

699 UV-C irradiation, peracetic acid, freezing/thawing, air-drying), should be explored.

700 Different inactivation methods were recently shown to affect the efficiency and accuracy 
Running Header: Long-amplicon PMA-qPCR assay for enumeration of viable $L$. monocytogenes

of short-amplicon PMA-qPCR and EMA-qPCR to detect viable Campylobacter

(Vondrakova et al., 2018).

In conclusion, the application of a long-amplicon PMA-qPCR assay to assess the survival of $L$. monocytogenes after heat treatment and desiccation with and without prior biofilm formation is promising and could be helpful in studies and surveillance of the survival and inactivation of $L$. monocytogenes in food processing environments.

\section{ACKNOWLEDGEMENTS}

This work was supported by start-up funds awarded to author Truelstrup Hansen from the National Food Institute at the Technical University of Denmark. Mia Laursen is thanked for her technical assistance.

\section{REFERENCES}

Agilent Technologies, 2012. Introduction to Quantitative PCR - Methods and Applications Guide. https://www.agilent.com/cs/library/brochures/Brochure_Guide to QPCR_IN70200C.pdf (accessed 2.28.19).

Allerberger, F., Wagner, M., 2010. Listeriosis: A resurgent foodborne infection. Clin. Microbiol. Infect. 16, 16-23. https://doi.org/10.1111/j.1469-0691.2009.03109.x

Banihashemi, A., Van Dyke, M.I., Huck, P.M., 2012. Long-amplicon propidium monoazide-PCR enumeration assay to detect viable Campylobacter and Salmonella. J. Appl. Microbiol. 113, 863-873. https://doi.org/10.1111/j.1365-2672.2012.05382.x Besnard, V., Federighi, M., Cappelier, J.M., 2000. Evidence of viable but non-culturable state in Listeria monocytogenes by direct viable count and CTC-DAPI double 
Running Header: Long-amplicon PMA-qPCR assay for enumeration of viable $L$. monocytogenes staining. Food Microbiol. 17, 697-704. https://doi.org/10.1006/fmic.2000.0366

Biotium, 2013. Viability PCR with PMA and PMAxx dyes. https://biotium.com/wpcontent/uploads/2013/07/PMAxx-PMA-Flyer.pdf (accessed 2.28.19).

Bustin, S.A., Jeremy A. Garson, Jan Hellemans, J.H., Kubista, M., Reinhold Mueller, Tania Nolan, Michael W. Pfaffl, Gregory L. Shipley, J.V., Wittwer, and C.T., 2009. The MIQE Guidelines: Minimum information for publication of quantitative realtime PCR experiments. Clin. Chem. 55, 611-622. https://doi.org/10.1373/clinchem.2008.112797

Cartwright et al, 2013. Listeriosis outbreaks and associated food vehicles, United States, 1998-2008. Emerg. Infect. Dis. 19, 1-10. https://doi.org/http://dx.doi.org/10.3201/eid1901.120393

Colagiorgi, A., Di Ciccio, P., Zanardi, E., Ghidini, S., Ianieri, A., 2016. A Look inside the Listeria monocytogenes Biofilms Extracellular Matrix. Microorganisms 4, 22. https://doi.org/10.3390/microorganisms4030022

Codony, F., Agusti, G., Allué-Guardia, A., 2015. Cell membrane integrity and distinguishing between metabolically active and inactive cells as a means of improving viability PCR. Mol. Cell Probes 29, 190-192. http://dx.doi.org/10.1016/j.mcp.2015.03.003

Ditommaso, S., Giacomuzzi, M., Ricciardi, E., Zotti, C.M., 2015. Viability-qPCR for detecting Legionella: Comparison of two assays based on different amplicon lengths. Mol. Cell. Probes 29, 237-243. https://doi.org/10.1016/j.mcp.2015.05.011 EFSA and ECDC (European Food Safety Authority and European Centre for Disease Prevention and Control), 2018. The European Union summary report on trends and 
Running Header: Long-amplicon PMA-qPCR assay for enumeration of viable $L$. monocytogenes

sources of zoonoses, zoonotic agents and food-borne outbreaks in 2017. EFSA J. 16, 262. https://doi.org/10.2903/j.efsa.2018.5500

EFSA BIOHAZ Panel (EFSA Panel on Biological Hazards), Ricci A, Allende A, Bolton D, Chemaly M, Davies R, Fernandez Escamez PS, Girones R, Herman L, Koutsoumanis K, Nørrung B, Robertson L, Ru G, Sanaa M, Simmons M, Skandamis P, Snary E, Speybroeck N, Ter Kuile B, Threlfall J, Wahlström H, Takkinen J, Wagner M, Arcella D, Da Silva Felicio MT, Georgiadis M, Messens W and Lindqvist R, 2018. Scientific opinion on the Listeria monocytogenes contamination of ready-to-eat foods and the risk for human health in the EU. EFSA Journal 2018; 16(1):5134, 173 pp. https://doi.org/ 10.2903/j.efsa.2018.5134

Ferrentino, G., Tamburini, S., Bath, K., Foladori, P., Spilimbergo, S., Jousson, O., 2015. Application of culture-independent methods for monitoring Listeria monocytogenes inactivation on food products. Process Biochem. 50, 188-193. https://doi.org/10.1016/j.procbio.2014.12.014

Fittipaldi, M., Nocker, A., Codony, F., 2012. Progress in understanding preferential detection of live cells using viability dyes in combination with DNA amplification. J. Microbiol. Methods 91, 276-289. https://doi.org/10.1016/j.mimet.2012.08.007

Flekna, G., Štefanič, P., Wagner, M., Smulders, F.J.M., Možina, S.S., Hein, I., 2007. Insufficient differentiation of live and dead Campylobacter jejuni and Listeria monocytogenes cells by ethidium monoazide (EMA) compromises EMA/real-time PCR. Res. Microbiol. 158, 405-412. https://doi.org/10.1016/j.resmic.2007.02.008

Gilmour, M.W., Graham, M., Van Domselaar, G., Tyler, S., Kent, H., Trout-Yakel, K.M., Larios, O., Allen, V., Lee, B., Nadon, C., 2010. High-throughput genome 
Running Header: Long-amplicon PMA-qPCR assay for enumeration of viable $L$. monocytogenes

sequencing of two Listeria monocytogenes clinical isolates during a large foodborne outbreak. BMC Genomics 11, 120. https://doi.org/10.1186/1471-2164-11-120

Glaser, P., Frangeul, L., Buchrieser, C., Rusniok, C., Amend, A., Baquero, F., Berche, P., Bloecker, H., Brandt, P., Chakraborty, T., Charbit, A., Chetouani, F., Couvé, E., de Daruvar, A., Dehoux, P., Domann, E., Domínguez-Bernal, G., Duchaud, E., Durant, L., Dussurget, O., Entian, K.D., Fsihi, H., García-del Portillo, F., Garrido, P., Gautier, L., Goebel, W., Gómez-López, N., Hain, T., Hauf, J., Jackson, D., Jones, L.M., Kaerst, U., Kreft, J., Kuhn, M., Kunst, F., Kurapkat, G., Madueno, E., Maitournam, A., Vicente, J.M., Ng, E., Nedjari, H., Nordsiek, G., Novella, S., de Pablos, B., Pérez-Diaz, J.C., Purcell, R., Remmel, B., Rose, M., Schlueter, T., Simoes, N., Tierrez, A., Vázquez-Boland, J.A., Voss, H., Wehland, J., Cossart, P., 2001. Comparative genomics of Listeria species. Science 294, 849-52. https://doi.org/10.1126/science.1063447

Guilbaud, M., Coppet, P. De, Bourion, F., Rachman, C., Dousset, X., 2005. Quantitative detection of Listeria monocytogenes in biofilms by real-time PCR. Society 71, 2190-2194. https://doi.org/10.1128/AEM.71.4.2190

Hingston, P.A., Stea, E.C., Knøchel, S., Truelstrup Hansen, L., 2013. Role of initial contamination levels, biofilm maturity and presence of salt and fat on desiccation survival of Listeria monocytogenes on stainless steel surfaces. Food Microbiol. 36, 46-56. https://doi.org/10.1016/j.fm.2013.04.011

Hingston, P. A., Chen, J., Dhillon, B. K., Laing, C., Bertelli, C., Gannon, V., Tasara, K., Allen, K., Brinkman, F.S.L., Truelstrup Hansen, L, Wang, S., 2017. Genotypes associated with Listeria monocytogenes isolates displaying impaired or enhanced 
Running Header: Long-amplicon PMA-qPCR assay for enumeration of viable $L$. monocytogenes

tolerances to cold, salt, acid, or desiccation stress. Front. Microbiol., 8, [369]. https://doi.org/10.3389/fmicb.2017.00369

Huang, Y., Truelstrup Hansen, L., Ragush, C.M., Jamieson, R.C., 2017. Disinfection and removal of human pathogenic bacteria in arctic waste stabilization ponds. Environ. Sci. Pollut. Res. 25, 32881-32893. https://doi.org/10.1007/s11356-017-8816-9

Jian, Y., George, C., Irena, Z., Ioana, C., Steve, R., Madden Thomas, L., 2012. PrimerBLAST: A tool to design target-specific primers for polymerase chain reaction. BMC Bioinformatics 13, 134. https://doi.org/10.1186/1471-2105-13-134

Josephson, K.L., Gerba, C.P., Pepper, I.L., 1993. Polymerase chain reaction detection of nonviable bacterial pathogens. Appl. Environ. Microbiol. 59, 3513-3515. https://doi.org/10.1107/S1600576714005214

Kalmokoff, M.L., Austin, J.W., Wan, X.D., Sanders, G., Banerjee, S., Farber, J.M., 2001. Adsorption, attachment and biofilm formation among isolates of Listeria monocytogenes using model conditions. J. Appl. Microbiol. 91, 725-734. https://doi.org/10.1046/j.1365-2672.2001.01419.x

Keskinen, L.A., Todd, E.C.D., Ryser, E.T., 2008. Transfer of surface-dried Listeria monocytogenes from stainless steel knife blades to roast turkey breast. J. Food Prot. 71, 176-181. https://doi.org/10.4315/0362-028X-71.1.176

Leriche, V., Carpentier, B., 1995. Viable but nonculturable Salmonella typhimurium in single-species and binary-species biofilms in response to chlorine treatment. J. Food Prot. 58, 1186-1191. https://doi.org/10.4315/0362-028X-58.11.1186

Lindbäck, T., Rottenberg, M.E., Roche, S.M., Rørvik, L.M., 2010. The ability to enter into an avirulent viable but non-culturable (VBNC) form is widespread among 
Running Header: Long-amplicon PMA-qPCR assay for enumeration of viable $L$. monocytogenes Listeria monocytogenes isolates from salmon, patients and environment. Vet. Res. 41, 08. https://doi.org/10.1051/vetres/2009056

Løvdal, T., Hovda, M.B., Björkblom, B., Møller, S.G., 2011. Propidium monoazide combined with real-time quantitative PCR underestimates heat-killed Listeria innocua. J. Microbiol. Methods 85, 164-169. https://doi.org/10.1016/j.mimet.2011.01.027

Martin, B., Raurich, S., Garriga, M., Aymerich, T., 2013. Effect of amplicon length in propidium monoazide quantitative PCR for the enumeration of viable cells of Salmonella in cooked ham. Food Anal. Methods 6, 683-690. https://doi.org/10.1007/s12161-012-9460-0

Midelet, G., Kobilinsky, A., Carpentier, B., 2006. Construction and analysis of fractional multifactorial designs to study attachment strength and transfer of Listeria monocytogenes from pure or mixed biofilms after contact with a solid model food. Appl. Environ. Microbiol. 72, 2313-2321. https://doi.org/10.1128/AEM.72.4.23132321.2006

Murray, E.G.D., Webb, R.A., Swann, M.B.R., 1926. A disease of rabbits characterised by a large mononuclear leucocytosis, caused by a hitherto undescribed bacillus Bacterium monocytogenes (n.sp.). J. Pathol. Bacteriol. 29, 407-439. https://doi.org/10.1002/path.1700290409

Nocker, A., Cheung, C.Y., Camper, A.K., 2006. Comparison of propidium monoazide with ethidium monoazide for differentiation of live vs. dead bacteria by selective removal of DNA from dead cells. J. Microbiol. Methods 67, 310-320. https://doi.org/10.1016/j.mimet.2006.04.015 
Running Header: Long-amplicon PMA-qPCR assay for enumeration of viable $L$. monocytogenes

Nolan, T., Huggett, J., Sanchez, E., 2013. Good Practice Guide for the Application of Quantitative PCR (qPCR). LGC. https://www.gene-quantification.de/nationalmeasurement-system-qpcr-guide.pdf

Overney, A., Jacques-André-Coquin, J., Ng, P., Carpentier, B., Guillier, L., Firmesse, O., 2017. Impact of environmental factors on the culturability and viability of Listeria monocytogenes under conditions encountered in food processing plants. Int. J. Food Microbiol. 244, 74-81. https://doi.org/10.1016/j.ijfoodmicro.2016.12.012

Pan, Y., Breidt, F., 2007. Enumeration of viable Listeria monocytogenes cells by realtime PCR with propidium monoazide and ethidium monoazide in the presence of dead cells. Appl. Environ. Microbiol. 73, 8028-8031. https://doi.org/10.1128/AEM.01198-07

Qiagen, 2006. DNeasy Blood \& Tissue Handbook. http://diagnostics1.com/MANUAL/General_Qiagen.pdf

Rodríguez, A., McLandsborough, L.A., 2007. Evaluation of the transfer of Listeria monocytogenes from stainless steel and high-density polyethylene to bologna and American cheese. J. Food Prot. 70, 600-6. https://doi.org/10.4315/0362-028X70.3.600

Ross, T., 1996. Indices for performance evaluation of predictive models in food microbiology. J. Appl. Bacteriol. 81, 501-508. https://doi.org/10.1111/j.13652672.1996.tb03539.x

Soejima, T., Iida, K.I., Qin, T., Taniai, H., Seki, M., Yoshida, S.I., 2008. Method to detect only live bacteria during PCR amplification. J. Clin. Microbiol. 46, 23052313. https://doi.org/10.1128/JCM.02171-07 
Running Header: Long-amplicon PMA-qPCR assay for enumeration of viable $L$. monocytogenes

Soejima, T., Iwatsuki, K.J., 2016. Innovative use of palladium compounds to selectively detect live Enterobacteriaceae in milk by PCR. Appl. Environ. Microbiol. 82, 69306941. https://doi.org/10.1128/AEM.01613-16

Soejima, T., Schlitt-Dittrich, F., Yoshida, S., 2011. Polymerase chain reaction amplification length-dependent ethidium monoazide suppression power for heatkilled cells of Enterobacteriaceae. Anal. Biochem. 418, 37-43. https://doi.org/10.1016/j.ab.2011.06.027

Takahashi, H., Gao, Y., Miya, S., Kuda, T., Kimura, B., 2017. Discrimination of live and dead cells of Escherichia coli using propidium monoazide after sodium dodecyl sulfate treatment. Food Control 71, 79-82. https://doi.org/10.1016/j.foodcont.2016.06.022

Thanh, M.D., Agustí, G., Mader, A., Appel, B., Codony, F., 2017. Improved sample treatment protocol for accurate detection of live Salmonella spp. in food samples by viability PCR. PLoS One 12, 1-12. https://doi.org/10.1371/journal.pone.0189302

Todd, E.C.D., Notermans, S., 2011. Surveillance of listeriosis and its causative pathogen, Listeria monocytogenes. Food Control 22, 1484-1490. https://doi.org/10.1016/j.foodcont.2010.07.021

Vogel, B. F., Hansen, L. T., Mordhorst, H., Gram, L., 2010. The survival of Listeria monocytogenes during long term desiccation is facilitated by sodium chloride and organic material. Int. J. Food Microbiol., 140(2-3), 192-200. https://doi.org/10.1016/j.ijfoodmicro.2010.03.035

Vondrakova, L., Turonova, H., Scholtz, V., Pazlarova, J., Demnerova, K., 2018. Impact of various killing methods on EMA/PMA-qPCR efficacy. Food Control 85, 23-28. 
Running Header: Long-amplicon PMA-qPCR assay for enumeration of viable $L$. monocytogenes

https://doi.org/10.1016/j.foodcont.2017.09.013

Winkelströter, L.K., De Martinis, E.C.P., 2015. Different methods to quantify Listeria monocytogenes biofilms cells showed different profile in their viability. Brazilian J. Microbiol. 46, 231-235. https://doi.org/10.1590/S1517-838220131071 
Running Header: Long-amplicon PMA-qPCR assay for enumeration of viable $L$. monocytogenes

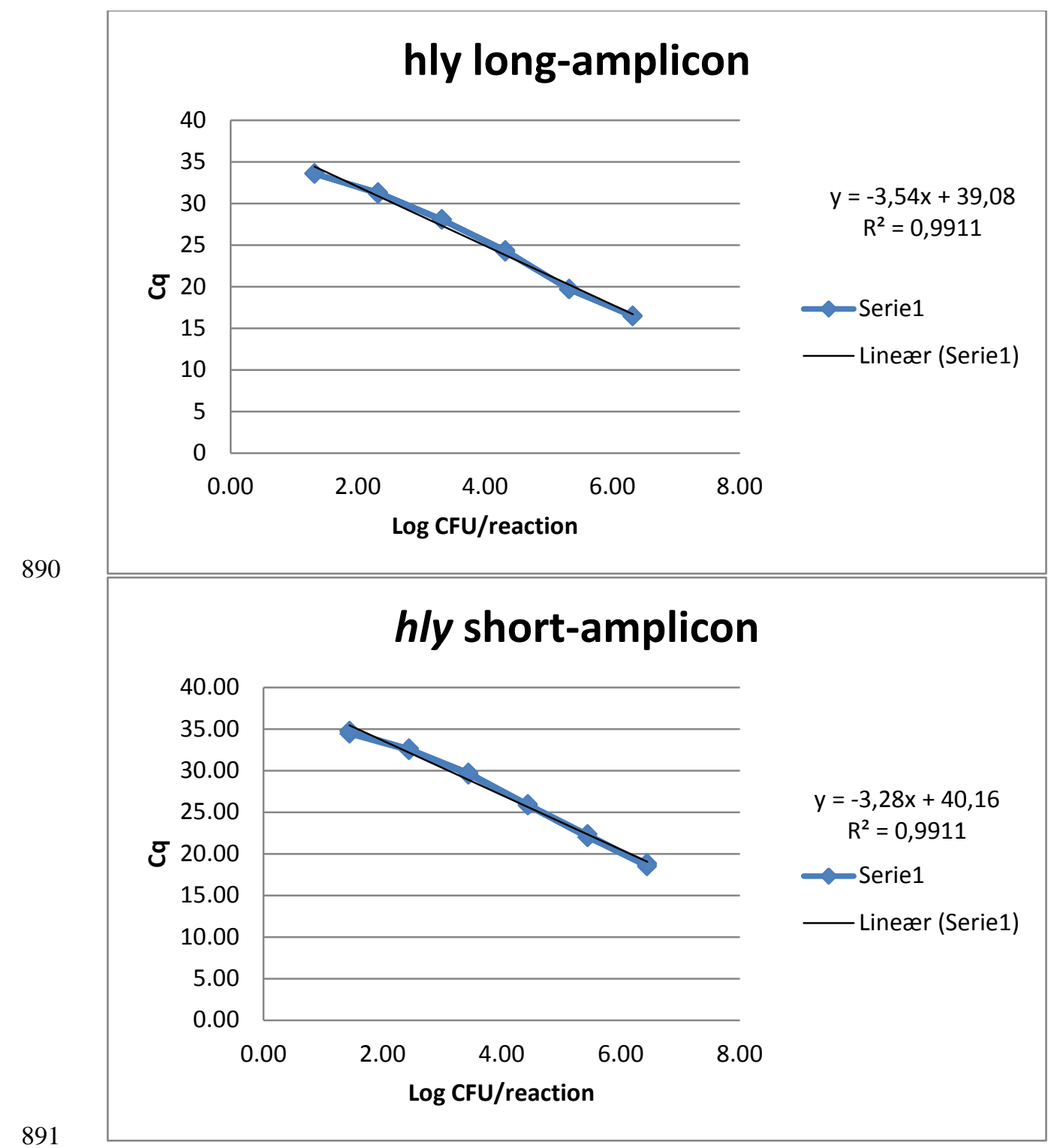

892

893

Figure S1. Standard curves for the hly long- and short-amplicon qPCR. 
Running Header: Long-amplicon PMA-qPCR assay for enumeration of viable $L$. monocytogenes

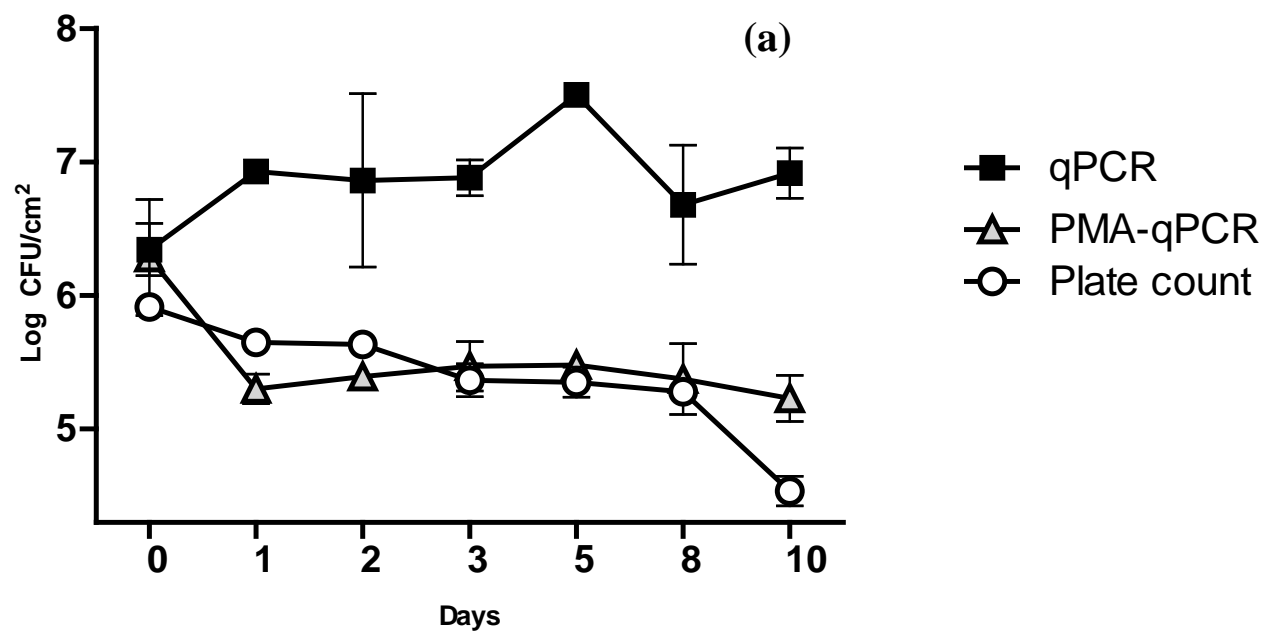

894

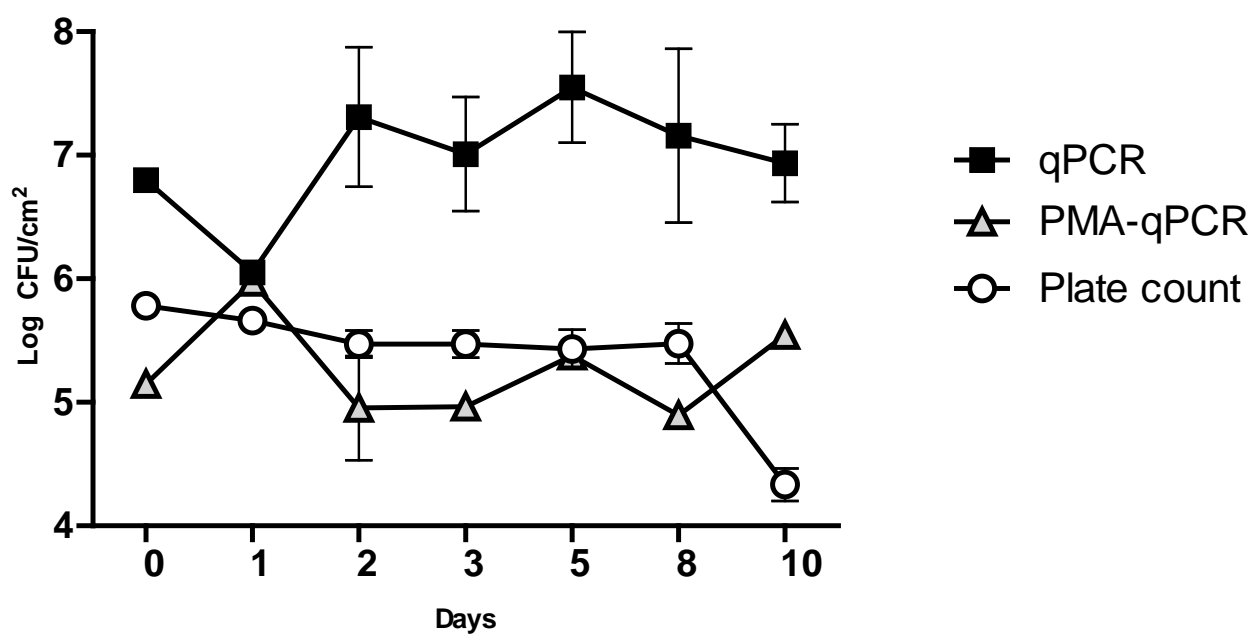

896 Figure S2. Desiccation survival of L. monocytogenes 08-5578 (a) and 568 (b) on stainless

897 steel coupons. Cells were pre-cultured at $15^{\circ} \mathrm{C}$ in TSB-glu and re-suspended in TSB-glu 898 and desiccated $\left(33 \% \mathrm{RH}, 15^{\circ} \mathrm{C}\right)$ for 10 days. Cells were enumerated by plate counts (O) 899 and the short-amplicon (SA, 199 bp) qPCR protocol with $(\Delta)$ or without (ם) PMA. 900 Symbols are averages of duplicates and error bars indicate standard deviation. 